\title{
Study of metal-lipopeptide complexes and their self-assembly behavior, micelle formation, interaction with bovine serum albumin and biological properties
}

\author{
Tomasz Janek $^{\mathrm{a}, *}$, Lígia R. Rodrigues ${ }^{\mathrm{b}}$, Żaneta Czyżnikowska ${ }^{\mathrm{a}}$ \\ a Wroclaw Medical University, Department of Inorganic Chemistry, Wroclaw, Poland \\ ${ }^{\mathrm{b}}$ University of Minho, Centre of Biological Engineering, Braga, Portugal
}

\section{A R T I C L E I N F O}

\section{Article history:}

Received 18 March 2018

Received in revised form 3 July 2018

Accepted 30 July 2018

Available online 01 August 2018

\section{Keywords:}

Biosurfactant

Lipopeptides

Circular dichroism

Molecular modelling

QSAR techniques

BSA

\begin{abstract}
A B S T R A C T
The present study aimed to explore the interactions of divalent counterions with biomolecular amphisin using circular dichroism (CD), ultraviolet-visible (UV-Vis) and density functional theory (DFT). The binding mode of interactions between metal-amphisin complexes and bovine serum albumin (BSA) were studied using fluorescence spectroscopy. The results showed that $\mathrm{Cu}^{2+}$ is coordinated by one oxygen atom of the aspartic acid side chain and three amide nitrogen atoms, whereas $\mathrm{Zn}^{2+}, \mathrm{Ca}^{2+}$ and $\mathrm{Mg}^{2+}$ favour the association with backbone oxygen atoms of the amphisin. On the other hand, the aggregation of amphisin induced by divalent counterions was studied by dynamic light scattering (DLS). Our results revealed that the self-assembly process of amphisin can be controlled by the addition of metal ions. The results of $C D$ spectra demonstrated that the binding of divalent counterions to the lipopeptide induces conformational changes in amphisin. Further studies using fluorescence spectroscopy showed that the metal-lipopeptide systems could interact with some functional groups of BSA, increasing the microenvironment around Trp residues of BSA. Thus, the interaction data acquired herein for the interesting class of complexes will be of significance in metal-based drug discovery and developmental research.
\end{abstract}

(c) 2018 Elsevier B.V. All rights reserved.

\section{Introduction}

Cyclic lipopeptides (CLPs) are surface active biosurfactants that are produced by a variety of microorganisms, including Gram-positive [1] and Gram-negative [2] bacteria. The best known CLPs are iturins, surfactins, lichenysins, fengycins and viscosins [3-6]. Due to their chemical structure, as well as biological and physiochemical properties, CLPS are a particularly promising class of biosurfactants. Indeed, CLPs compounds exhibit activities that make them potentially useful in industry, environmental protection and medical fields. Previous research has highlighted their potential use as antibacterial [7], antiviral [8], antifungal [9], or antitumor agents [10,11]. CLPs are synthesized by multifunctional non-ribosomal peptide synthetases (NRPS) [12]. The molecular basis of CLPs biosynthesis has been extensively reviewed by many authors $[13,14]$.

Amphisin is a lactam containing a $\beta$-hydroxydecanoyl fatty acid attached to an undecapeptide sequence (D-Leu-D-Asp-D-aThr-D-Leu-DLeu-D-Ser-L-Leu-D-Gln-L-Leu-L-Ile-L-Asp) which forms a cyclic lactone ring of the $\mathrm{D}$-threonine hydroxyl group onto the $\mathrm{C}$-terminal carboxylate.

\footnotetext{
* Corresponding author at: Wroclaw Medical University, Department of Inorganic Chemistry, Borowska 211a, PL-50556 Wrocław, Poland.

E-mail address: tomasz.w.janek@gmail.com (T. Janek).
}

Amphisin has a critical micellar concentration (CMC) of $0.075 \mathrm{mmol} \mathrm{L}^{-1}$ in water at $\mathrm{pH} 7.0$ [15]. Amphisin is responsible for the biological activities against the important plant-pathogenic microfungi Pythium ultimum and Rhizoctonia solani. It is worth mentioning that amphisin belongs to a class of microbial surface active compounds that are low toxicity and biodegradability $[16,17]$.

The metal ion coordination with metal chelating surfactant alters the ionic charge and/or molecular conformation of the surfactant and thus induces significant phase changes [18]. Recently, several experimental investigations have been devoted to understanding the biomolecular interactions between divalent counterions and cyclopeptides [19]. Such lipopeptide-metal complexes have gained greater self-assembly properties than the lipopeptide itself [20]. Previously, we studied conformational changes of metal-pseudofactin complexes by means of surface tension, DLS, computational and spectroscopic techniques. The addition of counterions was found to change the structure of pseudofactin, reduce the surface tension, and decrease the antimicrobial activity of lipopeptide against drug-resistant Staphylococcus epidermidis and Proteus mirabilis strains [21].

In order to characterize the basic features of metal-lipopeptide complexes and their potential application in medicine and drug delivery, we performed a detailed analysis of conformational changes and self-assembly of amphisin-lipopeptide biosurfactant. In comparison 
with the number of surfactants [22,23], a relatively few metalbiosurfactant systems have been investigated for BSA-binding activity. Therefore, the reactivity of metal-lipopeptide complexes towards BSA is useful in the design of metal-lipopeptide antibacterial and anticancer therapeutics.

In this work, the biomolecular interactions between divalent counterions and lipopeptide-amphisin were studied by ESI-MS, UV-Vis and $\mathrm{CD}$ spectroscopy. To address the binding of divalent cations to amphisin, the conformational analysis of their complexes was performed. Moreover, the experimental results were supported by calculations based on the DFT. A comparative study of the interactions of the metallipopeptide complexes with BSA was performed as well as the related biological activities were explored theoretically with QSAR techniques. The studies of the metal-amphisin complexes and its complexes with BSA are helpful to understand the effects of $\mathrm{Mg}^{2+}, \mathrm{Ca}^{2+}, \mathrm{Cu}^{2+}$ and $\mathrm{Zn}^{2}$ ${ }^{+}$on lipopeptide biological properties.

\section{Material and methods}

\subsection{Lipopeptide production and purification}

The Pseudomonas sp. strain DSS73 was graciously provided by Dr. Ole Nybroe (University of Copenhagen, Denmark). The strain DSS73 was grown on Davis minimal media (DMM; $30 \mathrm{mmol} \mathrm{L}{ }^{-1} \mathrm{~K}_{2} \mathrm{HPO}_{4}$, $14 \mathrm{mmol} \mathrm{L}^{-1} \mathrm{KH}_{2} \mathrm{PO}_{4}, 7.6 \mathrm{mmol} \mathrm{L}^{-1}\left(\mathrm{NH}_{4}\right)_{2} \mathrm{SO}_{4}, 0.4 \mathrm{mmol} \mathrm{L}^{-1} \mathrm{MgSO}_{4}$ and $120 \mathrm{mmol} \mathrm{L}^{-1}$ D-glucose. Growth on solid medium was performed on DMA (Davis Minimal Agar) with the same composition as DMM supplemented with agar $\left(15 \mathrm{~g} \mathrm{~L}^{-1}\right)$. The bacterial colonies were gently scraped off after 5 days incubation at $8{ }^{\circ} \mathrm{C}$ and resuspended in $15 \mathrm{~mL}$ phosphate-buffered saline (PBS). Crude biosurfactants were produced by gently stirring the suspensions in solution for $4 \mathrm{~h}$ at $8{ }^{\circ} \mathrm{C}$. The supernatant was lyophilized to dryness, and the crude extract was dissolved in methanol. Next, the lipopeptide was purified via reversed-phase high-performance liquid chromatography (RP-HPLC, Hitachi Primaide, Tokyo, Japan), equipped with an Xterra Prep RP18 OBD column (5 $\mu \mathrm{m}$, $18 \times 100 \mathrm{~mm}$; Waters, USA). The solvent system consisted of solvent A: $0.1 \%$ aqueous trifluoroacetic acid, and solvent B: $0.1 \%$ trifluoroacetic acid in acetonitrile. The lipopeptide was eluted at a flow rate of $4 \mathrm{~mL} \min ^{-1}$ with 45 -min gradient (\% A:B v/v): injection start (30:70), $20 \mathrm{~min}$ (10:80), $25 \mathrm{~min}$ (0:100), $35 \mathrm{~min}$ (0:100), $40 \mathrm{~min}$ (30:70), and $45 \mathrm{~min}(30: 70)$. Mass spectrometry of the purified amphisin revealed over $99 \%$ purity (Fig. S1).

\subsection{Mass spectrometry}

A Bruker compact ${ }^{\mathrm{TM}}$ mass spectrometer (Bruker Daltonics, Bremen, Germany) with electrospray ionization source in positive and negative ions mode was used. The purified amphisin $(1 \mathrm{mM})$ was dissolved in aqueous solution ( $\mathrm{MeOH} / \mathrm{ammonium}$ acetate; 50/50; $\mathrm{pH}=7.4$ ). The amphisin was supplemented with $\mathrm{CuCl}_{2}, \mathrm{ZnCl}, \mathrm{Mg}\left(\mathrm{NO}_{3}\right)_{2}$ and $\mathrm{CaCl}_{2}$ (molar ratio metal-amphisin $=1: 1$ and $2: 1$ ). A portion of the solutions $(80 \mu \mathrm{L})$ were introduced at a flow rate of $3 \mu \mathrm{L} \mathrm{min}{ }^{-1}$. The instrument parameters were as follows: scan range: $50-3000 \mathrm{~m} / \mathrm{z}$; temperature: $200{ }^{\circ} \mathrm{C}$, potential between the spray needle and the orifice: $4.0 \mathrm{kV}$, drying gas: nitrogen and flow rate: $4.0 \mathrm{~L} \mathrm{~min}^{-1}$.

\subsection{Spectroscopic studies of metal cation complexation}

The UV-visible molecular absorption spectra of the metal-amphisin complexes were monitored between 200 and $450 \mathrm{~nm}$ (Varian Carry 50 Bio spectrophotometer; Varian, USA). The concentration of amphisin $(0.5 \mathrm{mM})$ was diluted in $25 \mathrm{mM}$ ammonium acetate $(\mathrm{pH} 7.4)$ for all divalent metal ions measurements.

\subsection{CD spectroscopy}

Far-ultraviolet CD spectra (200-260 nm) of amphisin samples were performed using a spectropolarimeter J-1500 (JASCO, Tokyo, Japan) at room temperature $\left(25^{\circ} \mathrm{C}\right)$, equipped with $0.5 \mathrm{~cm}$ quartz cuvette. The spectra of amphisin were collected in the presence of various concentrations on $\mathrm{CuCl}_{2}, \mathrm{ZnCl}_{2}, \mathrm{Mg}\left(\mathrm{NO}_{3}\right)_{2}$ and $\mathrm{CaCl}_{2}(0.125-1 \mathrm{mM})$. Bandwidth was $2 \mathrm{~nm}$ and scanning speed was $50 \mathrm{~nm} \mathrm{~min}^{-1}$. Each spectrum represents the average of nine scans. The $\alpha$-helical and $\beta$-strand contents were calculated using BeStSel algorithm [24].

\subsection{Computational analysis}

In order to determine the structure of lipopeptide-metal complexes many different conformations were analyzed. The optimized geometries were identified as a global minimum on the potential energy surface by harmonic vibrational frequencies calculation at the PM6 level of theory. It was proved by Steward et al. its applicability to estimate the properties of biocomplexes with transition metals [25]. It is also a reasonable compromise between cost and accuracy of calculations. In present study, only the lowest energy conformers were presented. Solvent effects were included by using the polarizable continuum model (PCM) [26-28]. All calculations have been performed with the version of the Gaussian 09 program [29].

The molecular volume $\left(V_{\mathrm{mon}}^{\mathrm{B} \text { BLY }}\right)$ of the amphisin and its metal complexes were determined as the volume within a contour of 0.001 electrons/bohr ${ }^{3}$ density. The CAM-B3LYP/6-31 $++\mathrm{G}^{* *}$ level of theory was employed to describe the systems [30-33]. The length of the micellar radii $\left(R_{\mathrm{H}}^{\mathrm{PM} 6}\right)$, was taken as the distance between the farthest carbon atom one of Leu 5 and the carbon of the terminal methyl group of $\beta$-hydroxydecanoyl fatty acid side chain. The simulations of biological activity were performed using a combination of the 3D/4D QSAR BiS/MC and CoCon algorithms developed by the ChemoSophia Company [34-36].

\subsection{Surface tension measurements}

The surface tension measurements were performed using a Krüss K100 Tensiometer (Krüss GmbH, Hamburg, Germany) at $25^{\circ} \mathrm{C}$, according to the du Noüy's ring method [37]. Amphisin and metal ions were dissolved in $25 \mathrm{mM}$ ammonium acetate ( $\mathrm{pH} 7.4$ ) and mixed to obtain several mixtures containing a constant metal ions concentration ( $0.5 \mathrm{mM})$ while the amphisin concentration varied from 0.0022 to $0.09 \mathrm{mM}$. The surface tension of the control sample ( $25 \mathrm{mM}$ ammonium acetate ( $\mathrm{pH} 7.4$ )) was $70.1 \mathrm{mN} \mathrm{m}^{-1}$. The average equilibrium surface tension values were obtained by measuring each sample in triplicate.

\subsection{Micelles size measurement by DLS}

The size of the aggregates was examined by the dynamic light scattering technique using a photon correlation spectrometer Zetasizer Nano-ZS (Malvern, Worcestershire, UK). The scattering angle was $173^{\circ}$, and the experimental temperature was maintained at $25^{\circ} \mathrm{C}$. The average equilibrium size micelles were recorded in nine times.

\subsection{Fluorescence measurements}

The fluorescence quenching spectra and synchronous fluorescence spectra were obtained by a Cary Eclipse Fluorescence Spectrophotometer. The emission spectra were recorded in the wavelength range of $300-400 \mathrm{~nm}$ by exciting protein at $280 \mathrm{~nm}$ using excitation and emission slit width of $3 \mathrm{~nm}$ and $5 \mathrm{~nm}$ respectively. For synchronous fluorescence spectra $\Delta \lambda=20$ or $60 \mathrm{~nm}$, the emission wavelength ranged from 200 to $400 \mathrm{~nm}$. All the measurements were performed with the increasing concentrations of metal-amphisin complexes at 25, 30 and $37{ }^{\circ} \mathrm{C}$. All tested compounds were dissolved in $25 \mathrm{mM}$ 
Table 1

ESI-MS data of the cyclic lipopeptide amphisin at $\mathrm{pH} 7.4$ with $\mathrm{Cu}^{2+}, \mathrm{Zn}^{2+}, \mathrm{Mg}^{2+}$ and $\mathrm{Ca}^{2+}$ at a molar ratio of $1: 1 . \mathrm{L}=$ amphisin.

\begin{tabular}{llll}
\hline Complex & Calculated $^{\mathrm{a}}$ & Found $^{\mathrm{b}}$ & Relative intensity [\%] \\
\hline $\mathrm{Cu}^{2+}$-amphisin & & & \\
{$[\mathrm{L}+\mathrm{H}]^{+}$} & 1395.8345 & 1395.8602 & 3 \\
{$[\mathrm{~L}+\mathrm{Cu}-\mathrm{H}]^{+}$} & 1456.7485 & 1456.7675 & 100 \\
$\mathrm{Zn}^{2+}$-amphisin $^{+}$ & & & \\
{$[\mathrm{L}+\mathrm{H}]^{+}$} & 1395.8345 & 1395.8602 & 2 \\
{$[\mathrm{~L}+\mathrm{Zn}-\mathrm{H}]^{+}$} & 1457.7480 & 1457.7816 & 98 \\
$\mathrm{Mg}^{2+}$-amphisin & & & \\
{$[\mathrm{L}+\mathrm{H}]^{+}$} & 1395.8345 & 1395.8553 & 9 \\
{$[\mathrm{~L}+\mathrm{Mg}-\mathrm{H}]^{+}$} & 1417.8039 & 1417.8327 & 100 \\
$\mathrm{Ca}^{2+}$-amphisin & & & \\
{$[\mathrm{L}+\mathrm{H}]^{+}$} & 1395.8345 & 1395.8552 & 6 \\
{$[\mathrm{~L}+\mathrm{Ca}-\mathrm{H}]^{+}$} & 1433.7815 & 1433.8078 & 100 \\
\hline
\end{tabular}

a Monoisotopic mass of the indicated ion formed by the ligand calculated by Compass DataAnalysis 4.2.

b Monoisotopic mass found experimentally on a compact ${ }^{\mathrm{TM}}$ mass spectrometer.

ammonium acetate buffer ( $\mathrm{pH} 7.4$ ); The concentration of BSA was determined from optical density measurements using the values of $\varepsilon_{280}=44,720 \mathrm{M}^{-1} \mathrm{~cm}^{-1}$. Quenching parameters were calculated from the Stern-Volmer equation [38]:

$F_{0} / F=1+K_{\mathrm{SV}}[\mathrm{Q}]=1+k_{\mathrm{q}} \tau_{0}[\mathrm{Q}]$

where $F_{0}$ and $F$ are the fluorescence intensities in the absence and presence of quencher (metal-lipopeptide complex), respectively, $K_{\mathrm{SV}}$ is the Stern-Volmer quenching constant, [Q] is the concentration of quencher, $k_{\mathrm{q}}$ is the biomolecular quenching rate constant, and $\tau_{0}$ is the lifetime of the fluorophore. The fluorescence lifetime of BSA is about $5 \mathrm{~ns}$ [39]. For the static quenching interaction, the binding constant $\left(K_{\mathrm{b}}\right)$ and the number of binding sites $(n)$ can be determined by the following equation:

$$
\log \left[\left(F_{0}-F\right) / F\right]=\log K_{\mathrm{b}}+n \log [\mathrm{Q}]
$$

where $F_{0}$ and $F$ are the fluorescence intensities in the absence and presence of quencher (metal-lipopeptide complex), respectively, [Q] is the concentration of quencher.

\section{Results and discussion}

\subsection{ESI-MS and UV-Vis measurements}

The ESI-MS method has been used in a wide variety of fields to study the speciation, stoichiometry, and formation of metal-ligand complexes [40]. The ESI-MS spectra (Fig. S2) obtained for the $\mathrm{Cu}^{2+}, \mathrm{Zn}^{2+}, \mathrm{Mg}^{2+}$ or $\mathrm{Ca}^{2+} /$ amphisin (molar ratio $\mathrm{n}_{\text {Metal }}: \mathrm{n}_{\text {Ligand }}=1: 1$ ) systems recorded in the positive mode show dominant molecular ions of the mononuclear complexes: $\mathrm{Cu}^{2+}$-amphisin ( $\left.\mathrm{m} / \mathrm{z} 1456.76 \mathrm{Da}\right), \mathrm{Zn}^{2+}$-amphisin $(\mathrm{m} / \mathrm{z}$ 1457.78 Da), $\mathrm{Mg}^{2+}$-amphisin ( $m / z$ 1417.83 Da), and $\mathrm{Ca}^{2+}$-amphisin $(\mathrm{m} / z 1433.80 \mathrm{Da})$. As shown in Table 1, the ESI-MS systems support the formation of the mononuclear complexes under the MS experimental conditions. Addition of an excess of $\mathrm{Cu}^{2+}, \mathrm{Zn}^{2+}, \mathrm{Mg}^{2+}$ or $\mathrm{Ca}^{2+}$ ions (molar ratio $\mathrm{n}_{\text {Metal }}: \mathrm{n}_{\text {Ligand }}=2: 1$ ) favours the formation of complexes with a 1:1 stoichiometry. A previous study of the interaction of natural lipopeptide gramicidin $\mathrm{S}$ with a series alkali metals indicated that the monovalent cations are bound to the exterior of the peptide ring, thus avoiding the charge repulsion of two alkali cations in the interior
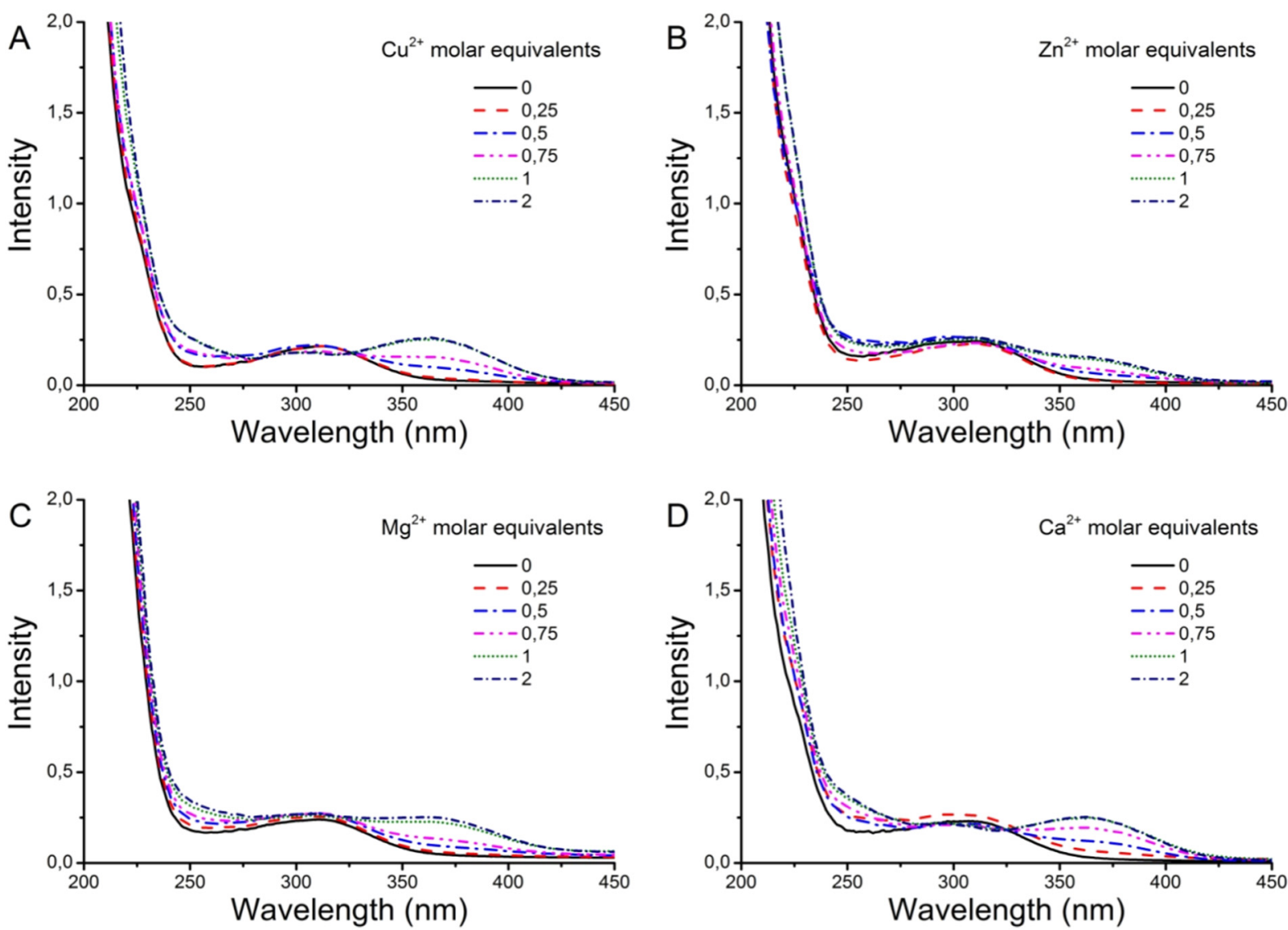

Fig. 1. The changes in UV-Vis spectra of amphisin at different ratios of $\mathrm{Cu}^{2+}(\mathrm{A}), \mathrm{Zn}^{2+}(\mathrm{B}), \mathrm{Mg}^{2+}(\mathrm{C})$ and $\mathrm{Ca}^{2+}(\mathrm{D})$ to lipopeptide $\left(0.5 \mathrm{mmol} \mathrm{L}^{-1}\right)$. 
of the peptide ring [41]. In our previous work, we observed that pseudofactin II was also linked with only one metal cation and favours the formation of mononuclear complexes [21].

In order to confirm complexation of amphisin with divalent counterions, series of UV-Vis spectra of the amphisin in the presence of $\mathrm{Cu}^{2+}$, $\mathrm{Zn}^{2+}, \mathrm{Mg}^{2+}$ or $\mathrm{Ca}^{2+}$ ions at $\mathrm{pH} 7.4$ were recorded. Fig. 1 presents the spectral absorbance changes of amphisin upon addition of metal ions. The UV-Vis spectrum of the amphisin showed one band at $310 \mathrm{~nm}$. The absorption spectra (Fig. 1A) of $\mathrm{Cu}^{2+}$-amphisin complex solution shows an absorbance band centered at $360 \mathrm{~nm}$ while the peak at $310 \mathrm{~nm}$ was decreased. The results suggest that copper coordination occurred, and stable complexes increased linearly with an increase the concentration of $\mathrm{Cu}^{2+}$ up to molar ratio of 1:1 and remained as a plateau upon adding more $\mathrm{Cu}^{2+}$ metal ions. Absorption spectra were next recorded with other metal ions, such as $\mathrm{Zn}^{2+}, \mathrm{Mg}^{2+}$ and $\mathrm{Ca}^{2+}$ (see Fig. 1B-D), and they exhibited similar absorbance change at $360 \mathrm{~nm}$. Overall, the results of band shifts suggested that amphisin could bind with divalent metal ions and form mononuclear complexes.

\subsection{Conformational analysis}

In order to present the structural properties of the amphisin-cation complexes semi-empirical calculations were performed at PM6 level of theory. The obtained conformations for free and complexes of amphisin were presented in Fig. 2. In the present study we report only the lowestenergy conformers. The conformational analysis was performed taking
Amphisin

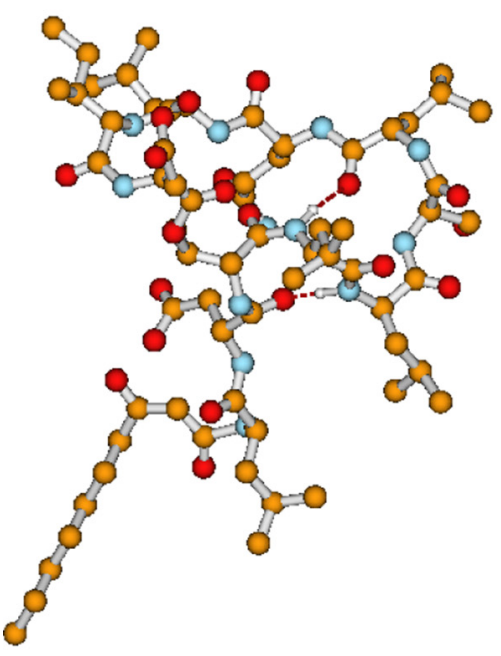

$$
\mathrm{Cu}^{2+} \text {-amphisin }
$$

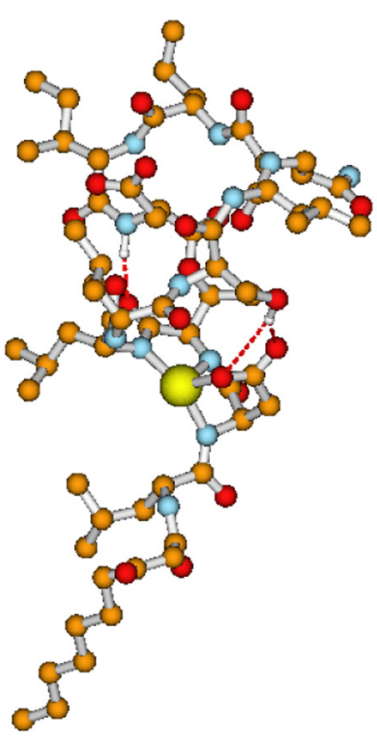

$\mathrm{Zn}^{2+}-$ amphisin

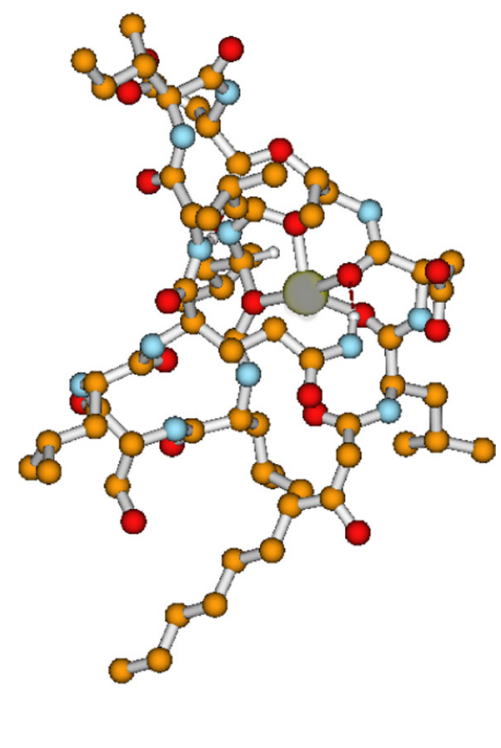

$\mathrm{Mg}^{2+}-$ amphisin

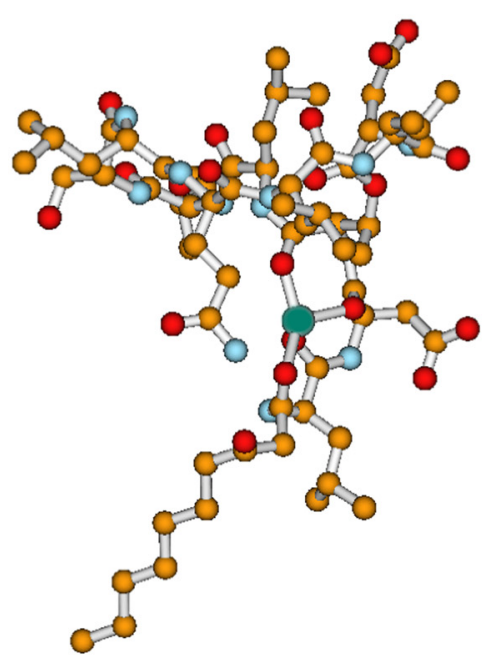

$\mathrm{Ca}^{2+}-\mathbf{a m p h i s i n}$

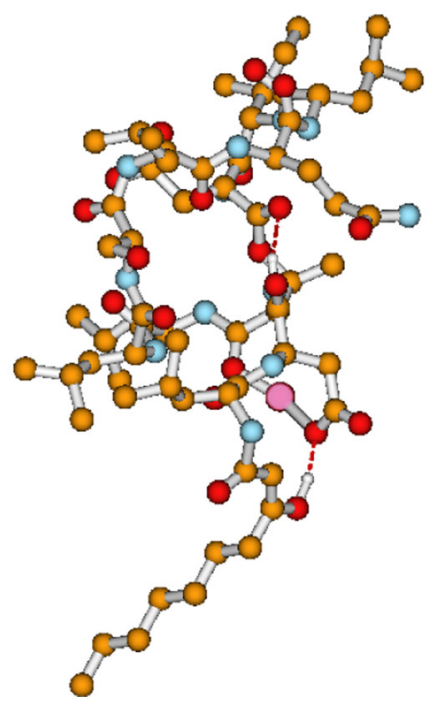

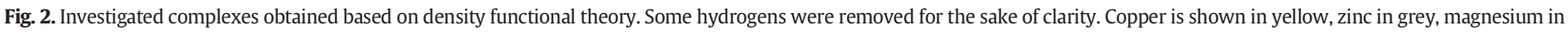

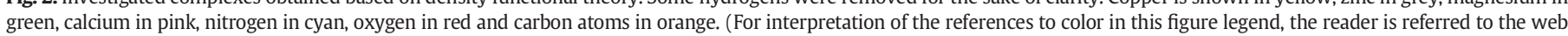
version of this article.) 

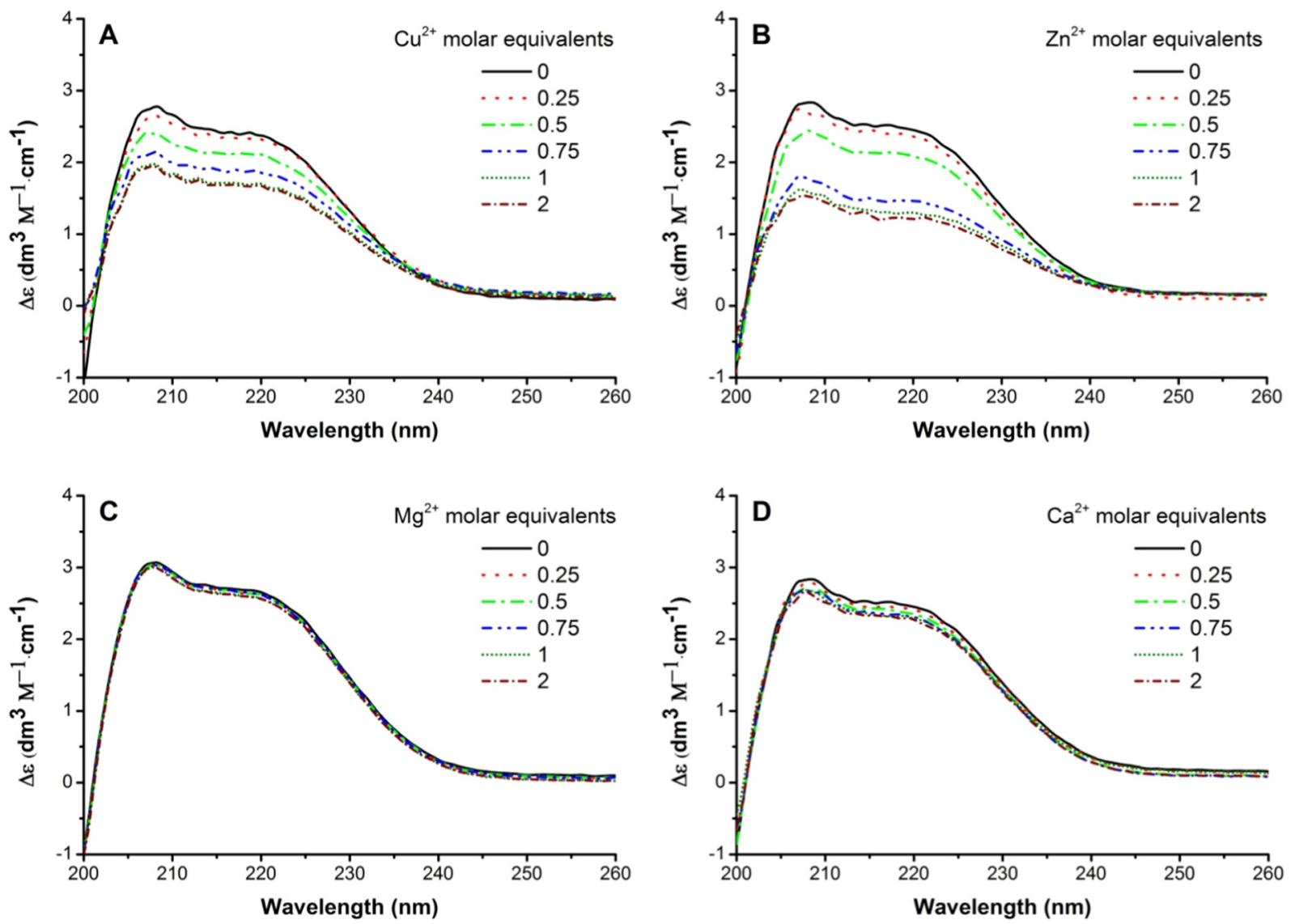

Fig. 3. $\mathrm{CD}$ spectra of amphisin at different concentrations of $\mathrm{Cu}^{2+}(\mathrm{A}), \mathrm{Zn}^{2+}(\mathrm{B}), \mathrm{Mg}^{2+}(\mathrm{C})$ and $\mathrm{Ca}^{2+}(\mathrm{D})$.

in to consideration the results of previous research on the impact of $\mathrm{Cu}^{2+}, \mathrm{Zn}^{2+}, \mathrm{Mg}^{2+}$ and $\mathrm{Ca}^{2+}$ on the binding properties of lipopeptides and cyclic peptides $[21,42,43]$. It should be underlined that for most analyzed conformation we obtained stable lipopeptide-metal complexes what supports our experimental results. The geometry of metal bonded conformers strongly correlates with the cation binding manner.

As can be observed in Fig. 2 two hydrogen bonds (equal 1.5 and $2.0 \AA$ ) are involved in stabilization the cyclic structure of free lipopeptide. The significant change in the mutual position of hydrophilic and hydrophobic groups of amphisin was observed after ion binding. In accordance with previous findings [42], three amide nitrogens can coordinate $\mathrm{Cu}^{2+}$ ion in planar configurations. Additionally, in this complex the oxygen atom from the side chain of the Asp amino acid is directly involved in metal ion binding (Fig. 2). Three hydrogen bonds (1.5, 1.9 and $2.8 \AA$ ) may be one of the factors that can increase the stabilization of the analyzed systems. However, another metal bonding manner (see Fig. 2) by four oxygen donor atoms in an almost tetrahedral configuration has been observed in the case of $\mathrm{Zn}^{2+}$-amphisin complexes. Two oxygens are from the hydrophilic chain and two from the cycle part of amphisin in which the calcium oxygen-distances were set to $2.1 \AA$ A. The oxygens of side chains of aspartic acids are not involved in complex formation. In this case, there is also the largest modification of lipopeptide conformation due to the binding of metal. We have also found the presence of two moderate hydrogen bonds both of length $2.0 \AA$. In Fig. 2 the structure of amphisin- $\mathrm{Mg}^{2+}$ complex was presented. The conformation of the complex does not change significantly after magnesium substitution and the metal is coordinated by four carbonyl oxygens. Similarly, as in our previous work we were not able to determine stable tri- and tetra-coordinated complexes with $\mathrm{Ca}^{2+}$ ion [21]. In this case metal is coordinated by two oxygens and structural differences upon calcium binding are much smaller in comparison to the changes occurring upon of zinc ion binding.

Table 2

Selected properties of the micellar systems studied. Experimental results represent the mean of 9 replicates \pm SD.

\begin{tabular}{|c|c|c|c|c|c|}
\hline & Amphisin & $\mathrm{Cu}^{2+}$-amphisin & $\mathrm{Zn}^{2+}$-amphisin & $\mathrm{Mg}^{2+}$-amphisin & $\mathrm{Ca}^{2+}$-amphisin \\
\hline \multicolumn{6}{|l|}{$D L S$} \\
\hline PdI & $0.132 \pm 0.012$ & $0.175 \pm 0.009$ & $0.219 \pm 0.021$ & $0.177 \pm 0.016$ & $0.191 \pm 0.009$ \\
\hline$R_{\mathrm{H}}^{(\mathrm{DLS})}[\mathrm{nm}]$ & $2.22 \pm 0.12$ & $2.72 \pm 0.21$ & $2.14 \pm 0.15$ & $2.32 \pm 0.18$ & $2.41 \pm 0.09$ \\
\hline$V_{\mathrm{mic}}^{(\mathrm{DLS})}\left[\mathrm{nm}^{3}\right]$ & 45.83 & 84.29 & 41.05 & 52.30 & 58.63 \\
\hline \multicolumn{6}{|l|}{ DFT } \\
\hline$R_{\mathrm{H}}^{(\mathrm{DFT})}[\mathrm{nm}]$ & 2.18 & 2.51 & 2.09 & 2.28 & 2.36 \\
\hline$V_{\text {mon }}\left[\mathrm{nm}^{3}\right]$ & 1.89 & 1.99 & 1.85 & 2.01 & 1.94 \\
\hline$V_{\mathrm{mic}}^{(\mathrm{DFT})}\left[\mathrm{nm}^{3}\right]$ & 43.54 & 66.80 & 38.7 & 49.51 & 55.49 \\
\hline$N_{\mathrm{agg}}^{(\mathrm{DFT})}$ & 23 & 33 & 21 & 24 & 28 \\
\hline
\end{tabular}

$V_{\mathrm{mic}}^{(\mathrm{DLS})}={ }^{4} / 3 \cdot \pi \cdot\left(R_{\mathrm{H}}^{(\mathrm{DLS})}\right)^{3} ; V_{\mathrm{mic}}^{(\mathrm{DFT})}=4 / 3 \cdot \pi \cdot\left(R_{\mathrm{H}}^{(\mathrm{DFT})}\right)^{3} ; N_{\mathrm{agg}}=V_{\mathrm{mic}}^{(\mathrm{DFT})} / V_{\mathrm{mon}}^{(\mathrm{DFT})}$. 
Table 3

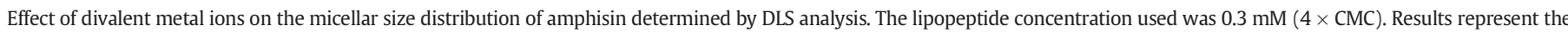
mean of 9 replicates \pm SD.

\begin{tabular}{|c|c|c|c|c|c|c|c|c|}
\hline \multirow[t]{2}{*}{ Concentration (mM) } & \multicolumn{2}{|l|}{$\mathrm{Cu}^{2+}$} & \multicolumn{2}{|l|}{$\mathrm{Zn}^{2+}$} & \multicolumn{2}{|l|}{$\mathrm{Mg}^{2+}$} & \multicolumn{2}{|l|}{$\mathrm{Ca}^{2+}$} \\
\hline & Size (nm) & PdI & Size (nm) & PdI & Size (nm) & PdI & Size (nm) & PdI \\
\hline 0 & $65.2 \pm 0.8$ & $0.092 \pm 0.004$ & $65.2 \pm 0.8$ & $0.092 \pm 0.004$ & $65.2 \pm 0.8$ & $0.092 \pm 0.004$ & $65.2 \pm 0.8$ & $0.092 \pm 0.004$ \\
\hline 0.15 & $110.4 \pm 2.1$ & $0.143 \pm 0.012$ & $70.1 \pm 1.2$ & $0.212 \pm 0.002$ & $74.3 \pm 1.8$ & $0.201 \pm 0.012$ & $92.5 \pm 0.1$ & $0.105 \pm 0.012$ \\
\hline 0.3 & $131.5 \pm 1.1$ & $0.187 \pm 0.002$ & $71.6 \pm 2.0$ & $0.172 \pm 0.006$ & $78.3 \pm 1.4$ & $0.142 \pm 0.003$ & $107.3 \pm 0.5$ & $0.201 \pm 0.006$ \\
\hline 0.6 & $150.9 \pm 0.5$ & $0.156 \pm 0.007$ & $72.5 \pm 0.2$ & $0.301 \pm 0.012$ & $87.1 \pm 0.7$ & $0.187 \pm 0.015$ & $122.6 \pm 1.1$ & $0.199 \pm 0.004$ \\
\hline
\end{tabular}

\section{3. $C D$ spectroscopy}

Fig. 3 shows the effect of $\mathrm{Cu}^{2+}, \mathrm{Zn}^{2+}, \mathrm{Mg}^{2+}$ or $\mathrm{Ca}^{2+}$ ions on the $\mathrm{CD}$ spectrum of amphisin. This spectrum shows two peaks at 208 and $222 \mathrm{~nm}$, which could be explained by the $n \pi^{*}$ transition occurred within D-amino acids. The broad positive band at $208 \mathrm{~nm}$ could then be interpreted as the inverse $\alpha$-helical conformation involving D-amino acids. With the increase of divalent counterions, the $\alpha$-helicity of amphisin was changed. $\mathrm{CD}$ spectra of free amphisin at $25{ }^{\circ} \mathrm{C}$ yielded a $66.42 \% \alpha$-helical and only $0.72 \% \beta$-strand structure. The addition of $0.5 \mathrm{mmol} \mathrm{L}^{-1}$ of $\mathrm{Cu}^{2+}$ and $\mathrm{Zn}^{2+}$ to amphisin (molar ratio $\mathrm{n}_{\mathrm{Me}}: \mathrm{n}_{\mathrm{L}}=1: 1$ ) caused a conformational modification of the amphisin to $36.73 \%$ $\alpha$-helical $/ 8.21 \% \beta$-strand and $23.72 \% \alpha$-helical $/ 14.06 \% \beta$-strand, respectively. The helical content was found to decrease from $66.42 \%$ $\alpha$-helical $/ 0.72 \% \beta$-strand for native amphisin to $62.31 \% \alpha$-helical/ $1.71 \% \beta$-strand and $51.22 \% \alpha$-helical $/ 2.12 \% \beta$-strand in presence of $0.5 \mathrm{mmol} \mathrm{L}^{-1} \mathrm{Mg}^{2+}$ and $\mathrm{Ca}^{2+}$, respectively. In summary, these observations clearly illustrate that the $\mathrm{Cu}^{2+}, \mathrm{Zn}^{2+}$ and $\mathrm{Ca}^{2+}$ play a major role in the changes of the secondary structure of amphisin (Fig. 3). This was further confirmed by the studies on the conformational analysis for metal-amphisin complexes (Fig. 2).

\subsection{Surface tension and size of micelles study}

In this study, the surface tension profiles were obtained for amphisin alone and in the presence of metal ions (Fig. S3). In the case of amphisin with or without metal ions, CMC values can be observed as the saturation of the interface is reached. For the amphisin in ammonium acetate buffer solution, the CMC value was $0.075 \mathrm{mM}$. The $\mathrm{CMC}$ values for the metal-amphisin complexes were lower in the presence of $\mathrm{Cu}^{2+}, \mathrm{Zn}^{2+}$, $\mathrm{Mg}^{2+}$ or $\mathrm{Ca}^{2+}$ ions. Compared with the amphisin solution without metal ions, the CMCs of $\mathrm{Mg}^{2+}$-amphisin and $\mathrm{Ca}^{2+}$-amphisin decreased from $0.075 \mathrm{mM}$ to $0.03 \mathrm{mM}$ and $0.02 \mathrm{mM}$, respectively. Similar reductions in the CMC with increasing concentrations of the $\mathrm{Cu}^{2+}$ and $\mathrm{Zn}^{2+}$ counterions was also observed. The addition of $0.5 \mathrm{mM}$ of $\mathrm{Cu}^{2+}$ and $\mathrm{Zn}^{2+}$ to amphisin reduced the CMCs to $0.045 \mathrm{mM}$ and $0.04 \mathrm{mM}$, respectively. Our studies revealed that all the tested metal ions led to reductions of the surface tension values of amphisin, being these reductions
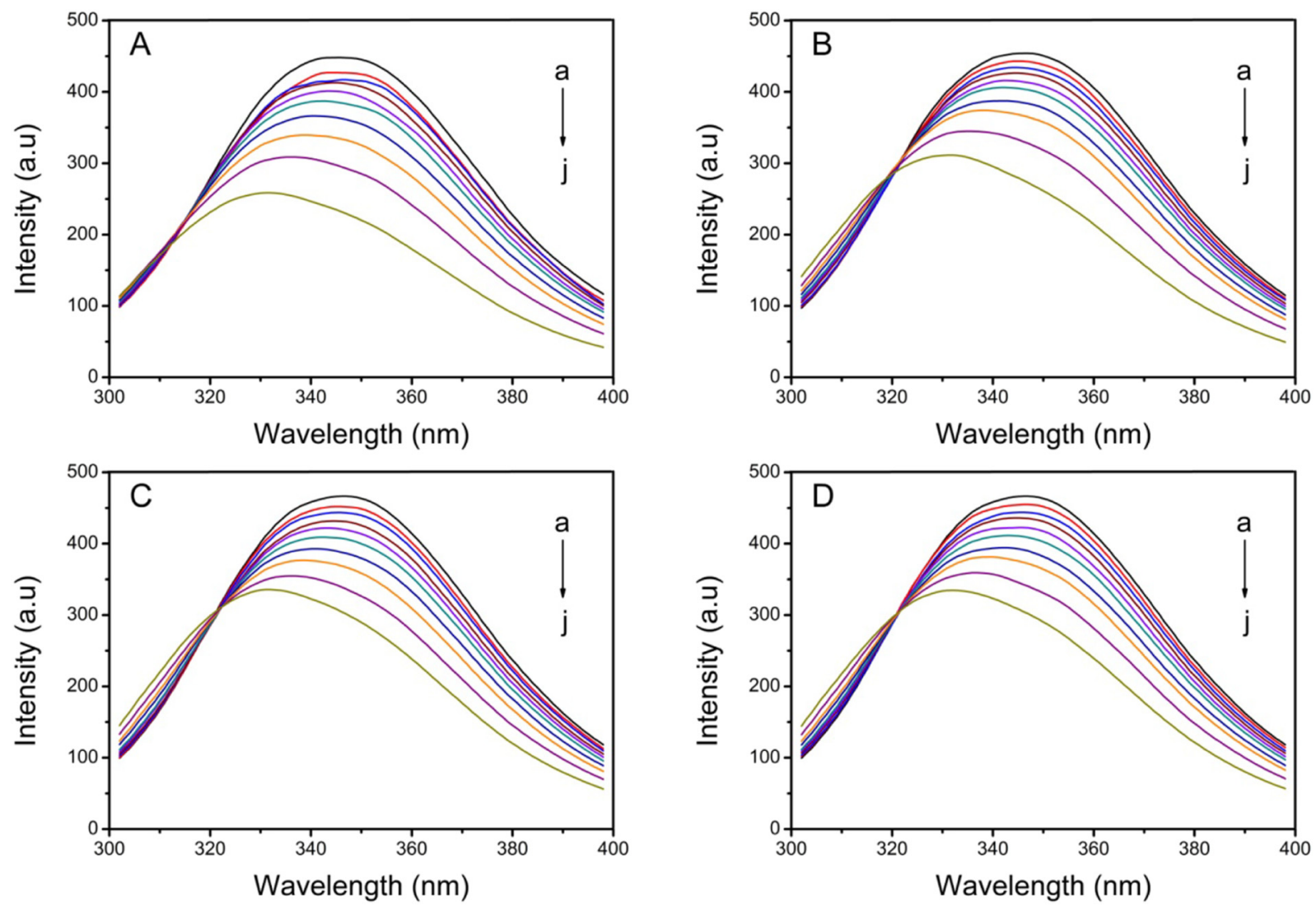

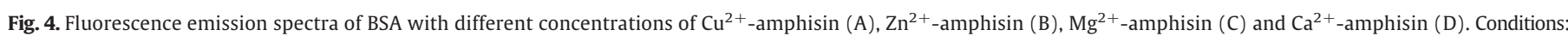
BSA: $1 \times 10^{-5} \mathrm{~mol} \mathrm{~L}^{-1}$; metal-lipopeptide $(\mathrm{a}-\mathrm{j}): 1.25 \times 10^{-5}, 2.5 \times 10^{-5}, 5 \times 10^{-5}, 7.5 \times 10^{-5}, 1 \times 10^{-4}, 1.25 \times 10^{-4}, 1.5 \times 10^{-4}, 2 \times 10^{-4}, 3 \times 10^{-4} \mathrm{~mol} \mathrm{~L}-1 ; \mathrm{pH}=7.4 ;$ and $\mathrm{T}=25^{\circ} \mathrm{C}$. 
obtained with $\mathrm{Cu}^{2+}, \mathrm{Ca}^{2+}, \mathrm{Mg}^{2+}$ and $\mathrm{Zn}^{2+}$ from $29.1 .5 \mathrm{mN} \mathrm{m}{ }^{-1}$ up to $24.5,25.1,26.3$ and $27.9 \mathrm{mN} \mathrm{m}^{-1}$, respectively.

In order to monitor the size of micelles of amphisin altered by divalent metal ions, the dynamic light scattering measurements were performed. Besides utilizing the DLS to detect amphisin aggregation, DFT calculation was also potentially useful for measuring hydrodynamic radius of amphisin aggregates, particle size distribution of the aggregates. The experimental micelle volumes and hydrodynamic radii with their theoretically calculated counterparts and aggregation numbers, are shown in Table 2 . The experimental hydrodynamic radii $\left(R_{\mathrm{H}}^{\mathrm{DLS}}\right)$ and theoretically calculated $\left(R_{\mathrm{H}}^{\mathrm{PM} 6}\right)$ of amphisin were $2.22 \mathrm{~nm}$ and 2.18 , respectively. Addition of copper, magnesium and calcium ions increases the size of the aggregation number $\left(N_{\mathrm{agg}}\right)$. On the other hand, addition of $\mathrm{Zn}^{2+}$ reduces the size of the microstructures and aggregation number by suppressing the formation of large aggregates. In this case, there are the largest modifications of lipopeptide conformation due to the binding of $\mathrm{Zn}^{2+}$. It was confirmed through the studies of the molecular modelling simulations (Fig. 2).

To understand the structure variation of the lipopeptide aggregates, we have studied the influence of the divalent counterions on the micelle size of the amphisin at and above the CMC values. The concentrations of amphisin used in these studies $(0.075 \mathrm{mM} \sim \mathrm{CMC}$ and $0.3 \mathrm{mM}(4 \times \mathrm{CMC}))$. The obtained $R_{\mathrm{H}}^{\mathrm{DLS}}$ of the aggregates of $0.075 \mathrm{mM}$ amphisin with $\mathrm{Cu}^{2+}, \mathrm{Zn}^{2+}, \mathrm{Mg}^{2+}$ or $\mathrm{Ca}^{2+}$ at molar ratio metal-amphisin $=1: 1$ are shown in Table 2 .

Metal-amphisin complexes tend to form higher-order microstructures of different sizes with increasing concentrations of the counterions (Table 3). The experimental data reveals that like ordinary classical surfactants, our metallolipopeptides also have the tendency to associate themselves and form micelles at critical micelle concentration. It is found that the size of the aggregates only slightly increased
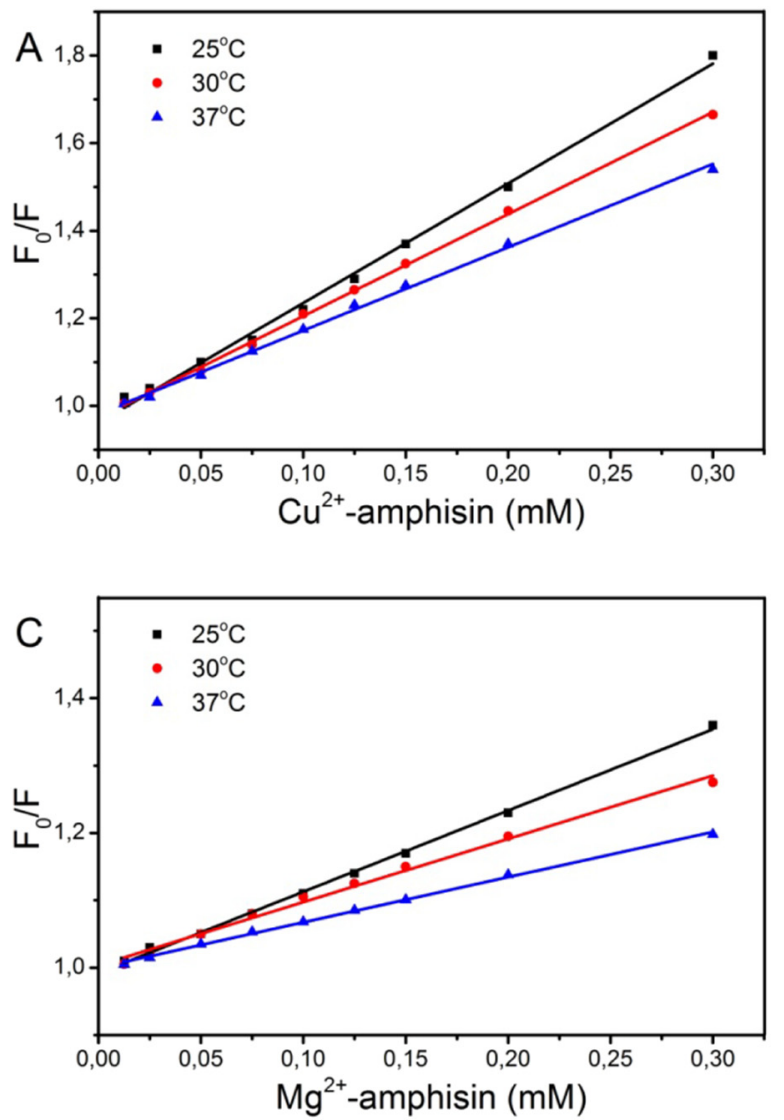

with the supplementation of $\mathrm{Zn}^{2+}$ and $\mathrm{Mg}^{2+}$, whereas the increase of $\mathrm{Cu}^{2+}$ and $\mathrm{Ca}^{2+}$ concentration led to a more significant growth of the amphisin micelles. Two main intermolecular forces determine the micellization of surfactant. Due to the presence of the lipid chain, the hydrophobic interactions increase their ability to form micelles. In the absence of metal ions, the negative charged head of amphisin due to the electrostatic repulsion hinder the micellization. The addition of metal ions influences self-organization properties of the lipopeptide. This is related to the electrostatic interactions occurring between divalent counterions with negative charged side chain of the aspartic acids which eliminate the repulsion of neighboring amphisin molecules and support the micelle formation. Our results are consistent with earlier reports on the self-aggregation ability of lipopeptides with calcium metal ion [44].

\subsection{Fluorescence measurements}

The effect of metal-amphisin complexes on intrinsic fluorescence of BSA is shown in Fig. 4. From this figure, it is observed that with increasing concentration of the metal-amphisin complexes the fluorescence intensity of BSA experienced a decreasing tendency which indicates the binding interaction between the metal-amphisin and BSA. When metal-amphisin concentration increases, the fluorescence intensity decreases and a blue shift from 345 to $331 \mathrm{~nm}$ is observed in the maximal intensity. This interaction takes place adjacent to the Trp in BSA and changes the polarity around the fluorophore. This phenomenon is ascribed to the formation of BSA-metal amphisin complex.

Fluorescence quenching can occur through dynamic and static mechanisms [45]. The involvement of two types of quenching mechanism, dynamic and static can be distinguished by the temperature dependent behavior of their Stern-Volmer quenching constants $\left(K_{\mathrm{SV}}\right)$.
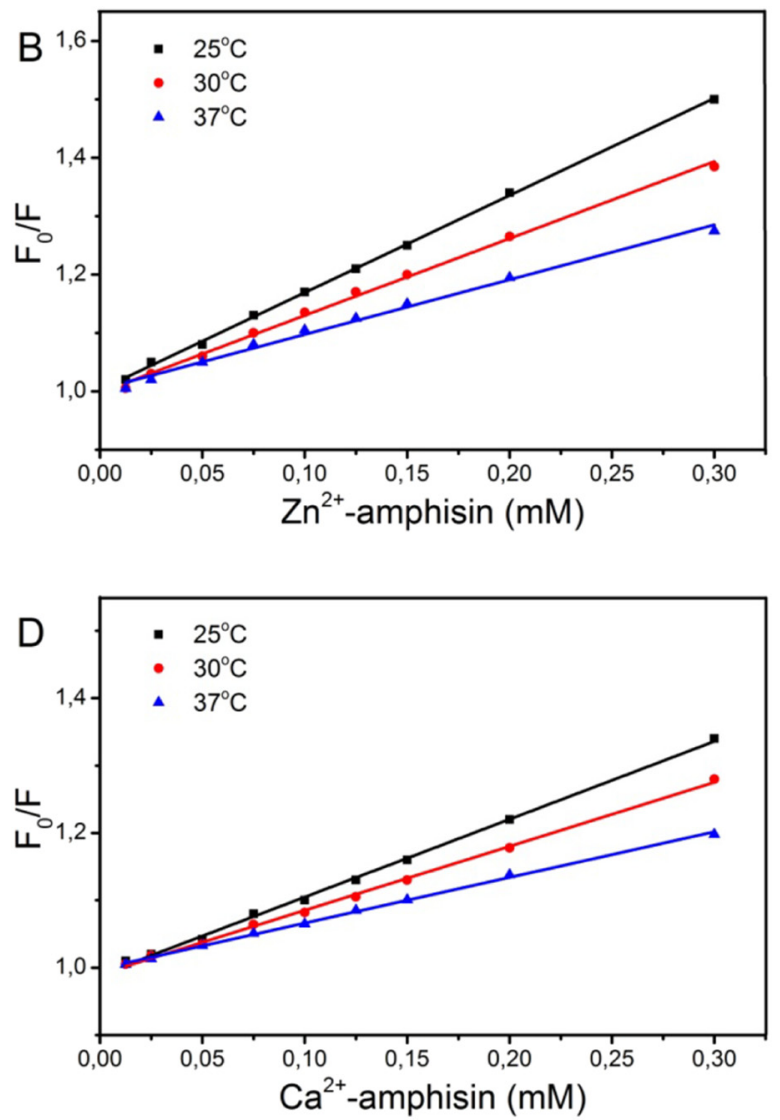

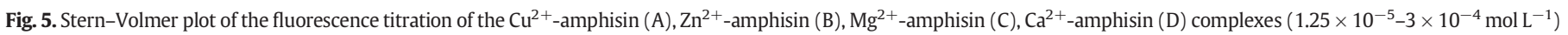
with BSA $\left(1 \times 10^{-5} \mathrm{~mol} \mathrm{~L}^{-1}\right)$. 
Table 4

Summary of Stern-Volmer data for BSA quenching by the metal-amphisin complexes.

\begin{tabular}{llllll}
\hline System & $T\left({ }^{\circ} \mathrm{C}\right)$ & $K_{\mathrm{SV}}\left(\mathrm{M}^{-1}\right)$ & $k_{\mathrm{q}}\left(\mathrm{M}^{-1} \mathrm{~s}^{-1}\right)$ & $R^{2}$ & $\mathrm{SD}$ \\
\hline $\mathrm{Cu}^{2+}$-amphisin & 25 & $2.731 \times 10^{3}$ & $5.462 \times 10^{11}$ & 0.996 & 0.03421 \\
& 30 & $2.329 \times 10^{3}$ & $4.658 \times 10^{11}$ & 0.999 & 0.01354 \\
$\mathrm{Zn}^{2+}$-amphisin & 37 & $1.902 \times 10^{3}$ & $3.804 \times 10^{11}$ & 0.998 & 0.02612 \\
& 35 & $1.665 \times 10^{3}$ & $3.330 \times 10^{11}$ & 0.999 & 0.01521 \\
& 30 & $1.319 \times 10^{3}$ & $2.638 \times 10^{11}$ & 0.998 & 0.02953 \\
$\mathrm{Mg}^{2+}$-amphisin & 25 & $0.939 \times 10^{3}$ & $1.878 \times 10^{11}$ & 0.996 & 0.03153 \\
& 30 & $0.939 \times 10^{3}$ & $1.878 \times 10^{11}$ & 0.995 & 0.03871 \\
$\mathrm{Ca}^{2+}$-amphisin & 37 & $0.671 \times 10^{3}$ & $1.342 \times 10^{11}$ & 0.998 & 0.01546 \\
& 25 & $1.156 \times 10^{3}$ & $2.312 \times 10^{11}$ & 0.997 & 0.02721 \\
& 30 & $0.951 \times 10^{3}$ & $1.902 \times 10^{11}$ & 0.996 & 0.03073 \\
& 37 & $0.678 \times 10^{3}$ & $1.356 \times 10^{11}$ & 0.998 & 0.02147 \\
\hline
\end{tabular}

The $K_{\mathrm{SV}}$ values decrease with an increase in temperature for static quenching, but the reverse effect will be observed for dynamic quenching [45]. In order to evaluate the mode of quenching, the SternVolmer equation (Eq. (1)) was used. Stern-Volmer quenching constant $\left(K_{\mathrm{SV}}\right)$ values were obtained from the slope of the regression curves. The linearity of Stern-Volmer plot reveals a single quenching mechanism operative in the binding process (Fig. 5). The $K_{\mathrm{SV}}$ values obtained from the Stern-Volmer plot (Table 4) decreases with the increase of temperature represents the involvement of static quenching. The $\mathrm{Cu}^{2+}$-amphisin complex was found to have a higher quenching constant (Table 4) compared to $\mathrm{Zn}^{2+}, \mathrm{Ca}^{2+}$ and $\mathrm{Mg}^{2+}$-amphisin complexes. For BSA, $\tau_{0}$ is known to be approximately $5 \times 10^{-9} \mathrm{~s}$, thus, $k_{\mathrm{q}}$ values were calculated and are illustrated in Table 4. From this table, it is observed that for all the BSA-metal-amphisin systems, the $k_{\mathrm{q}}$ values are in the order of $1.342 \times 10^{11}-5.462 \times 10^{11} \mathrm{M}^{-1} \mathrm{~s}^{-1}$. This higher value of $k_{\mathrm{q}}$ indicates that the quenching of Trp fluorescence occurred via a specific interaction between BSA and metal-amphisin, and the dominating quenching process belongs to the static quenching mechanism.

Using Eq. (2), the binding constant $\left(K_{\mathrm{b}}\right)$ and the number of binding sites $(n)$ values were obtained from the intercept and slope of the plots of $\log \left[\left(F_{0}-F\right) / F\right]$ versus $\log [Q]$ at $25{ }^{\circ} \mathrm{C}$ (Fig. 6). As shown in Table 5 , we observed that binding constant value of amphisin with $\mathrm{Cu}^{2+}$ was found to be greater than the respective amphisin complexes with $\mathrm{Zn}^{2+}, \mathrm{Mg}^{2+}$ and $\mathrm{Ca}^{2+}$. The values of $n$ obtained for metalamphisin complexes are approximately equal to 1 which indicates that there may be the existence of a single binding site for the metalamphisin complexes in BSA.

Synchronous fluorescence spectroscopy can give information about the molecular environment in the vicinity of a chromophore such as Trp and Tyr and it involves simultaneous scanning of the excitation

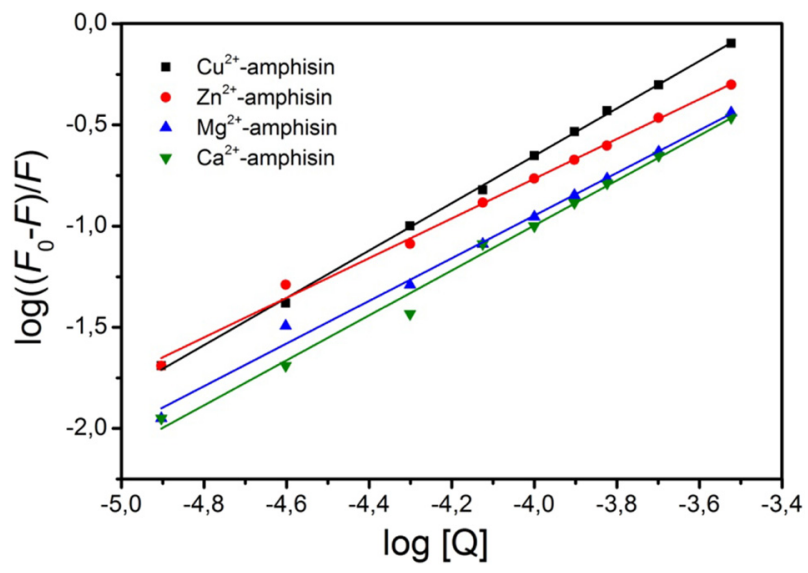

Fig. 6. The plots of $\log \left[\left(F_{0}-F\right) / F\right]$ versus $\log [\mathrm{Q}]$ for BSA-metal(II)-amphisin complexes at $25^{\circ} \mathrm{C}$.
Table 5

The binding constant $\left(K_{\mathrm{b}}\right)$ and binding site $(n)$ of BSA with metal-amphisin complexes at $25^{\circ} \mathrm{C}$.

\begin{tabular}{lllll}
\hline Complex & $K_{\mathrm{b}}\left(\mathrm{M}^{-1}\right)$ & $n$ & $R^{2}$ & $\mathrm{SD}$ \\
\hline $\mathrm{Cu}^{2+}$-amphisin & $1.065 \times 10^{4}$ & 1.17 & 0.999 & 0.000521 \\
$\mathrm{Zn}^{2+}$-amphisin & $0.144 \times 10^{4}$ & 0.98 & 0.998 & 0.000694 \\
$\mathrm{Mg}^{2+}$-amphisin & $0.186 \times 10^{4}$ & 1.05 & 0.996 & 0.000921 \\
$\mathrm{Ca}^{2+}$-amphisin & $0.281 \times 10^{4}$ & 1.11 & 0.997 & 0.000321 \\
\hline
\end{tabular}

and emission monochromators while maintaining a constant wavelength interval between them. When the wavelength interval $(\Delta \lambda)$ is set at 60 or $20 \mathrm{~nm}$, synchronous fluorescence generates the characteristic information of Trp or Tyr residues. As shown in Fig. 7, all tested metal-amphisin complexes increase the fluorescence intensity of Tyr $(\Delta \lambda=20 \mathrm{~nm})$, and decrease fluorescence intensity of $\operatorname{Trp}(\Delta \lambda=$ $60 \mathrm{~nm})$. The results show similar changes in the fluorescence intensity of BSA with cationic surfactants [46]. The result of synchronous fluorescence indicates that the binding of metal-amphisin complexes induce considerable conformational changes in the BSA. These observations illustrate that the metal-peptide group and the $\beta$-hydroxydecanoyl chain of the metal-amphisin complexes play a major role in the changes of the polarity around Trp residues.

\subsection{Drug potentiality}

A number of microbiological lipopeptides have been studied for their possible therapeutic potential. Lipopeptides have specific physicochemical properties that make them successful in medical applications. Some lipopeptides are suitable alternatives to antimicrobial and antitumor agents and may be used as safe and effective therapeutic agents $[47,48]$. In particular, through their ability to disturb the cell membranes integrity, destabilizing and permeabilizing them leading to metabolites leakage and ultimately to cell lysis [10]. Additionally, numerous drug delivery colloidal systems can be formulated using a mixture of structurally distinct surfactants, typically due to their self-assembly properties. This molecular self-assembly ability creates the possibility to use these compounds to dissolve and protect drugs from adverse external environments [49].

Coordination of bioactive molecules to metal ions is a common strategy to improve the therapeutic potency and/or to reduce the toxicity of drug molecules. In several cases, the metal-ligand complexes have been found to present a better biological activity than the ligands themselves [21]. The resulting metal-ligand complexes frequently possess superior lipophilicity profiles compared to the free ligands, allowing them to more easily pass through cell membranes and therefore, to exert their biological effects. In silico activity testing of metal-amphisin complexes shows very good activity as antibacterial ( $88.8 \%$ for $\mathrm{Ca}^{2+}$-amphisin) and anti-cancer (100\% for $\mathrm{Zn}^{2+}$-amphisin) agents (Table 6). Amphisin and metal-amphisin complexes have very good anti-herpes simplex virus activity. Antitumor anti-mitotic activity of $\mathrm{Cu}^{2+}$-amphisin and $\mathrm{Mg}^{2+}$-amphisin complexes derivatives are very high (>95\%) but that of $\mathrm{Zn}^{2+}$-amphisin and $\mathrm{Ca}^{2+}$-amphisin derivatives are within the required value (10-20\%). It is also possible for amphisin and metalamphisin complexes to be metabolized by CYP450-2D6, which is one of the most important enzyme which metabolize nearly $25 \%$ of clinical drugs. These in silico results suggest that metal-amphisin complexes can be used as potential antibacterial and antitumor agents.

\section{Conclusions}

In the current study, we have investigated the interactions between divalent counterions and amphisin by ESI-MS and CD spectroscopy, molecular modelling and DLS. It was found that only mononuclear complexes were obtained. The result of circular dichroism indicates that the binding of metal ions induce considerable conformational 
$\Delta \lambda=20 \mathrm{~nm}$
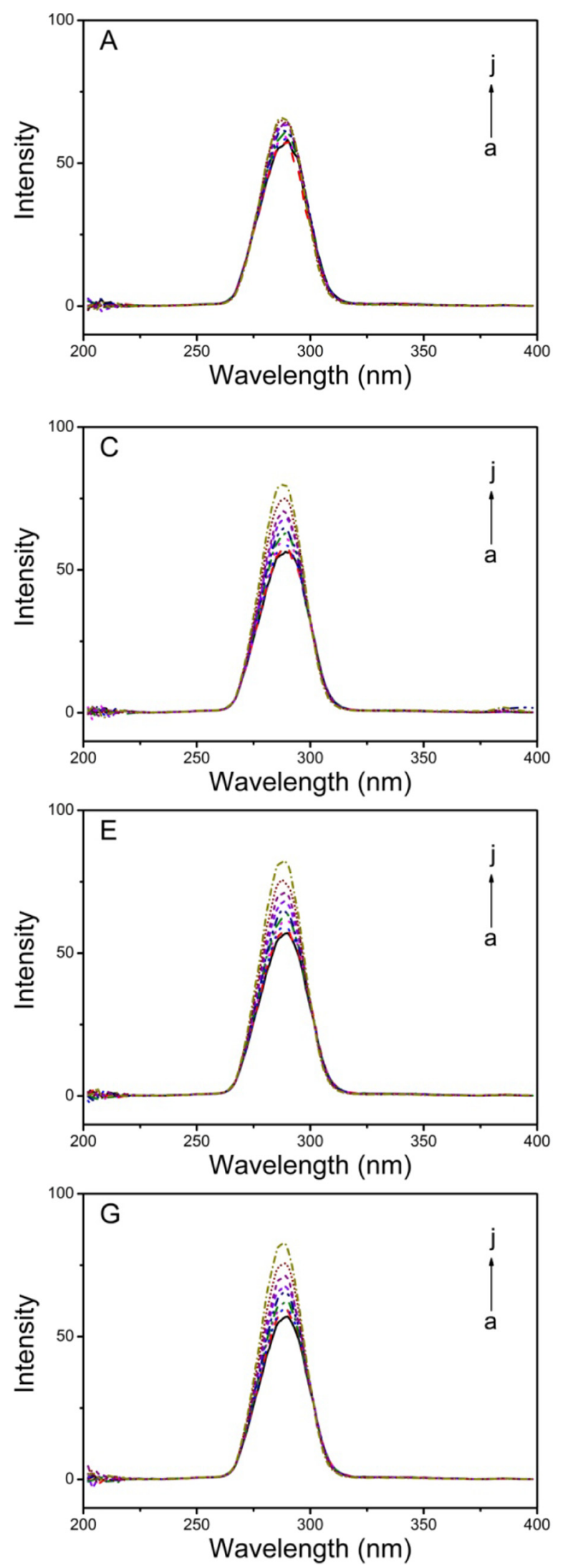

$\Delta \lambda=60 \mathrm{~nm}$
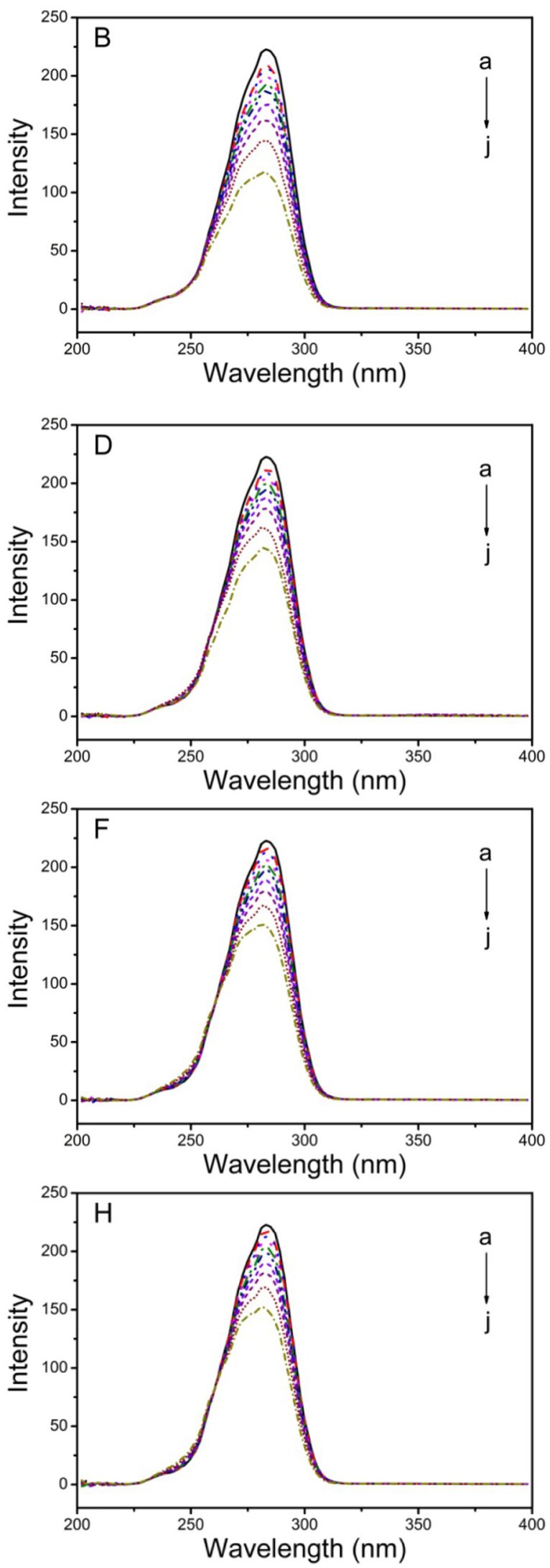

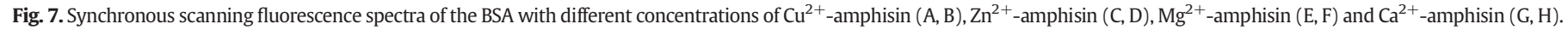

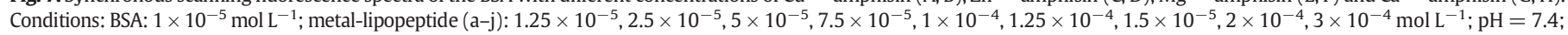
and $\mathrm{T}=25^{\circ} \mathrm{C}$. 
Table 6

Drug potentiality of amphisin complexes: an in silico test using the ChemoSophia [35] package.

\begin{tabular}{|c|c|c|c|c|c|}
\hline \multirow[t]{2}{*}{ Biological activity } & \multicolumn{5}{|c|}{ Success probability (\%) } \\
\hline & Amphisin & $\mathrm{Cu}^{2+}$-amphisin & $\mathrm{Zn}^{2+}$-amphisin & $\mathrm{Mg}^{2+}$-amphisin & $\mathrm{Ca}^{2+}$-amphisin \\
\hline Anti-adenovirus activity & 54.1 & 96.2 & 84.7 & 96.7 & 51.3 \\
\hline Antibacterial activity & 0 & 0 & 53.3 & 0 & 88.8 \\
\hline Anti-herpes simplex virus activity & 100 & 84.9 & 78.5 & 98.9 & 97.9 \\
\hline Antioxidant activity & 71.1 & 14.9 & 99.8 & 98.1 & 65.9 \\
\hline Antitumor anti-mitotic activity & 99.3 & 96.8 & 16.9 & 95.2 & 10.9 \\
\hline Antitumor dihydrofolate reductase inhibitory activity & 27.2 & 91.2 & 19.8 & 40.8 & 15.7 \\
\hline Antitumor DNA antimetabolitic activity & 99.9 & 100 & 99.9 & 99.5 & 0 \\
\hline Antitumor topoisomerase-I inhibitory activity & 98.6 & 99.8 & 100 & 0 & 32.5 \\
\hline Antitumor topoisomerase-II inhibitory activity & 0 & 0 & 0 & 99.3 & 99.9 \\
\hline Metabolism at CYP450-2D6 & 2.3 & 96.4 & 36.7 & 87.5 & 0 \\
\hline Metabolism at CYP450-3A4 & 78.7 & 8.3 & 100 & 91.7 & 89.5 \\
\hline
\end{tabular}

changes in the amphisin. The fluorescence spectra revealed that static quenching mechanism is operative during binding of metal-amphisin complexes with BSA. Thus, this study provides a significant perception towards the understanding of interactions between metal-amphisin systems and BSA. The biological activities of lipopeptide amphisin, together with their compatibility with divalent metal ions, make them promising alternatives to synthetic surfactant in a wide range of medical applications.

\section{Conflict of interest}

The authors declare that they have no competing interests.

\section{Acknowledgments}

This work was supported by Polish-Portugal Executive Program for years 2017-2018. Lígia Rodrigues acknowledges the Portuguese Foundation for Science and Technology (FCT) for the financial support under the scope of the strategic funding of SFRH/BSAB/142873/2018, UID/BIO/ 04469/2013 unit and COMPETE 2020 (POCI-01-0145-FEDER-006684). Żaneta Czyżnikowska gratefully acknowledges the allotment of the CPU time in Wroclaw Center of Networking and Supercomputing (WCSS).

\section{Appendix A. Supplementary data}

Supplementary data to this article can be found online at https://doi. org/10.1016/j.molliq.2018.07.118.

\section{References}

[1] S.A. Cochrane, J.C. Vederas, Lipopeptides from Bacillus and Paenibacillus spp.: a gold mine of antibiotic candidates, Med. Res. Rev. 36 (2016) 4-31, https://doi.org/10. 1002/med.21321.

[2] T. Janek, M. Łukaszewicz, T. Rezanka, A. Krasowska, Isolation and characterization of two new lipopeptide biosurfactants produced by Pseudomonas fluorescens BD5 isolated from water from the Arctic Archipelago of Svalbard, Bioresour. Technol. 101 (2010) 6118-6123, https://doi.org/10.1016/j.biortech.2010.02.109.

[3] P. Il Kim, J. Ryu, Y.H. Kim, Y.T. Chi, Production of biosurfactant lipopeptides iturin A, fengycin, and surfactin A from Bacillus subtilis CMB32 for control of Colletotrichum gloeosporioides, J. Microbiol. Biotechnol. 20 (2010) 138-145, https://doi.org/10. 4014/jmb.0905.05007.

[4] H. Suthar, A. Nerurkar, Characterization of biosurfactant produced by Bacillus licheniformis TT42 having potential for enhanced oil recovery, Appl. Biochem. Biotechnol. 180 (2016) 248-260, https://doi.org/10.1007/s12010-016-2096-6.

[5] B. Jasim, K.S. Sreelakshmi, J. Mathew, E.K. Radhakrishnan, Surfactin, iturin, and fengycin biosynthesis by endophytic Bacillus sp. from Bacopa monnieri, Microb. Ecol. 72 (2016) 106-119, https://doi.org/10.1007/s00248-016-0753-5.

[6] P. Biniarz, M. Łukaszewicz, T. Janek, Screening concepts, characterization and structural analysis of microbial-derived bioactive lipopeptides: a review, Crit. Rev. Biotechnol. 37 (2017) 393-410, https://doi.org/10.3109/07388551.2016.1163324.

[7] T. Janek, M. Łukaszewicz, A. Krasowska, Antiadhesive activity of the biosurfactant pseudofactin II secreted by the Arctic bacterium Pseudomonas fluorescens BD5, BMC Microbiol. 12 (2012) 24, https://doi.org/10.1186/1471-2180-12-24.
[8] M.A. Gordillo, M.C. Maldonado, Purification of peptides from Bacillus strains with biological activity, Chromatogr. Appl. (2009) 201-224.

[9] I. Mnif, A. Grau-Campistany, J. Coronel-León, I. Hammami, M.A. Triki, A. Manresa, D. Ghribi, Purification and identification of Bacillus subtilis SPB1 lipopeptide biosurfactant exhibiting antifungal activity against Rhizoctonia bataticola and Rhizoctonia solani, Environ. Sci. Pollut. Res. 23 (2016) 6690-6699, https://doi.org/10.1007/ s11356-015-5826-3.

[10] T. Janek, A. Krasowska, A. Radwańska, M. Łukaszewicz, Lipopeptide biosurfactant pseudofactin II induced apoptosis of melanoma A 375 cells by specific interaction with the plasma membrane, PLoS One 8 (2013), e57991. https://doi.org/10.1371/ journal.pone.0057991.

[11] E.J. Gudiña, V. Rangarajan, R. Sen, L.R. Rodrigues, Potential therapeutic applications of biosurfactants, Trends Pharmacol. Sci. 34 (2013) 667-675, https://doi.org/10. 1016/j.tips.2013.10.002.

[12] C.P. Strano, P. Bella, G. Licciardello, A. Fiore, A.R. Lo Piero, V. Fogliano, V. Venturi, V. Catara, Pseudomonas corrugata crpCDE is part of the cyclic lipopeptide corpeptin biosynthetic gene cluster and is involved in bacterial virulence in tomato and in hypersensitive response in Nicotiana benthamiana, Mol. Plant Pathol. 16 (2015) 495-506, https://doi.org/10.1111/mpp.12207.

[13] A.M. Gulick, Structural insight into the necessary conformational changes of modular nonribosomal peptide synthetases, Curr. Opin. Chem. Biol. 35 (2016) 89-96, https://doi.org/10.1016/j.cbpa.2016.09.005.

[14] M. Strieker, A. Tanović, M.A. Marahiel, Nonribosomal peptide synthetases: structures and dynamics, Curr. Opin. Struct. Biol. 20 (2010) 234-240, https://doi.org/ 10.1016/j.sbi.2010.01.009.

[15] A. Groboillot, F. Portet-Koltalo, F. le Derf, M.J.G. Feuilloley, N. Orange, C.D. Poc, Novel application of cyclolipopeptide amphisin: feasibility study as additive to remediate polycyclic aromatic hydrocarbon (PAH) contaminated sediments, Int. J. Mol. Sci. 12 (2011) 1787-1806, https://doi.org/10.3390/ijms12031787.

[16] T.H. Nielsen, D. Sørensen, C. Tobiasen, J.B. Andersen, C. Christophersen, M. Givskov, J. Sørensen, Antibiotic and biosurfactant properties of cyclic lipopeptides produced by fluorescent Pseudomonas spp. from the sugar beet rhizosphere, Appl. Environ. Microbiol. 68 (2002) 3416-3423, https://doi.org/10.1128/AEM.68.7.3416-3423. 2002.

[17] J.B. Andersen, B. Koch, T.H. Nielsen, D. Sørensen, M. Hansen, O. Nybroe, C Christophersen, J. Sørensen, S. Molin, M. Givskov, Surface motility in Pseudomonas sp. DSS73 is required for efficient biological containment of the root-pathogenic microfungi Rhizoctonia solani and Pythium ultimum, Microbiology 149 (2003) 37-46, https://doi.org/10.1099/mic.0.25859-0.

[18] T. Owen, A. Butler, Metallosurfactants of bioinorganic interest: coordinationinduced self assembly, Coord. Chem. Rev. 255 (2011) 678-687, https://doi.org/10. 1016/j.ccr.2010.12.009.

[19] J. Arutchelvi, J. Sangeetha, J. Philip, M. Doble, Self-assembly of surfactin in aqueous solution: role of divalent counterions, Colloids Surf. B: Biointerfaces 116 (2014) 396-402, https://doi.org/10.1016/j.colsurfb.2013.12.034.

[20] Y. Li, A.H. Zou, R.Q. Ye, B.Z. Mu, Counterion-induced changes to the micellization of surfactin-C16 aqueous solution, J. Phys. Chem. B 113 (2009) 15272-15277, https:// doi.org/10.1021/jp9062862.

[21] T. Janek, L.R. Rodrigues, E.J. Gudiña, Ż. Czyżnikowska, Structure and mode of action of cyclic lipopeptide pseudofactin II with divalent metal ions, Colloids Surf. B: Biointerfaces 146 (2016) 498-506, https://doi.org/10.1016/j.colsurfb.2016. 06.055 .

[22] J.K. Maurya, M.U.H. Mir, N. Maurya, N. Dohare, A. Ali, R. Patel, A spectroscopic and molecular dynamic approach on the interaction between ionic liquid type gemini surfactant and human serum albumin, J. Biomol. Struct. Dyn. 34 (2016)https://doi. org/10.1080/07391102.2015.1109552.

[23] N. Gull, J.M. Khan, Rukhsana, R.H. Khan, Spectroscopic studies on the gemini surfactant mediated refolding of human serum albumin, Int. J. Biol. Macromol. 102 (2017) 331-335, https://doi.org/10.1016/j.ijbiomac.2017.03.134.

[24] A. Micsonai, F. Wien, L. Kernya, Y.H. Lee, Y. Goto, M. Refregiers, J. Kardos, Accurate secondary structure prediction and fold recognition for circular dichroism spectroscopy, PNAS 112 (2015) E3095-E3103, https://doi.org/10.1073/pnas.1500851112.

[25] J.J.P. Stewart, Application of the PM6 method to modeling proteins, J. Mol. Model. 15 (2009) 765-805, https://doi.org/10.1007/s00894-008-0420-y. 
[26] J. Tomasi, B. Mennucci, R. Cammi, Quantum mechanical continuum solvation models, Chem. Rev. 105 (2005) 2999-3093, https://doi.org/10.1021/cr9904009.

[27] E. Cancès, B. Mennucci, J. Tomasi, A new integral equation formalism for the polarizable continuum model: theoretical background and applications to isotropic and anisotropic dielectrics, J. Chem. Phys. 107 (1997) 3032-3041, https://doi.org/10. 1063/1.474659.

[28] J. Tomasi, B. Mennucci, E. Cancès, The IEF version of the PCM solvation method: an overview of a new method addressed to study molecular solutes at the $\mathrm{QM}$ ab initio level, J. Mol. Struct. THEOCHEM 464 (1999) 211-226, https://doi.org/10.1016/ S0166-1280(98)00553-3.

[29] M.J. Frisch, G.W. Trucks, H.B. Schlegel, G.E. Scuseria, M.A. Robb, J.R. Cheeseman, G. Scalmani, V. Barone, B. Mennucci, G.A. Petersson, H. Nakatsuji, M. Caricato, X. Li, H.P. Hratchian, A.F. Izmaylov, J. Bloino, G. Zheng, Sonnenber, Gaussian 09, Gaussian, Inc., Wallingford CT, 2009 2-3 (doi:111).

[30] T. Yanai, D.P. Tew, N.C. Handy, A new hybrid exchange-correlation functional using the Coulomb-attenuating method (CAM-B3LYP), Chem. Phys. Lett. 393 (2004) 51-57, https://doi.org/10.1016/j.cplett.2004.06.011.

[31] C. Lee, W. Yang, R.G. Parr, Development of the Colle-Salvetti correlation-energy formula into a functional of the electron density, Phys. Rev. B 37 (1988) 785-789, https://doi.org/10.1103/PhysRevB.37.785.

[32] A.D. Becke, Density-functional exchange-energy approximation with correct asymptotic behavior, Phys. Rev. A 38 (1988) 3098-3100, https://doi.org/10.1103/ PhysRevA.38.3098.

[33] T. Wu, J. Kessler, P. Bour, Chiral sensing of amino acids and proteins chelating with EuIII complexes by raman optical activity spectroscopy, Phys. Chem. Chem. Phys. 18 (2016) 23803-23811, https://doi.org/10.1039/C6CP03968E.

[34] V. Potemkin, M. Grishina, Principles for 3D/4D QSAR classification of drugs, Drug Discov. Today 13 (2008) 952-959, https://doi.org/10.1016/j.drudis.2008.07.006.

[35] V.A. Potemkin, M.A. Grishina, A new paradigm for pattern recognition of drugs, ]. Comput. Aided Mol. Des. (2008) 489-505, https://doi.org/10.1007/s10822-0089203-X.

[36] V.A. Potemkin, M.A. Grishina, E.V. Bartashevich, Modeling of drug molecule orientation within a receptor cavity in the BiS algorithm framework, J. Struct. Chem. 48 (2007) 155-160, https://doi.org/10.1007/s10947-007-0023-y.

[37] C. Huh, S.G. Mason, Rigorous theory of ring tensiometry, Colloid Polym. Sci. 253 (1975) 566-580.

[38] W.M. Vaughan, G. Weber, Oxygen quenching of pyrenebutyric acid fluorescence in water. A dynamic probe of the microenvironment, Biochemistry 9 (1970) 464-473, https://doi.org/10.1021/bi00805a003.
[39] L. Shang, Y. Wang, J. Jiang, S. Dong, pH-dependent protein conformational changes in albumin: gold nanoparticle bioconjugates: a spectroscopic study, Langmuir 23 (2007) 2714-2721, https://doi.org/10.1021/la062064e.

[40] D. Brewer, G. Lajoie, Evaluation of the metal binding properties of the histidine-rich antimicrobial peptides histatin 3 and 5 by electrospray ionization mass spectrometry, Rapid Commun. Mass Spectrom. 14 (2000) 1736-1745, https://doi.org/10.1002/ 1097-0231(20001015)14:19<1736::AID-RCM86>3.0.CO;2-2.

[41] D.S. Gross, E.R. Williams, Structure of gramicidin S $(\mathrm{M}+\mathrm{H}+\mathrm{X}) 2+$ ions (X $=\mathrm{Li}$, Na, K) probed by proton transfer reactions, J. Am. Chem. Soc. 118 (1996) 202-204, https://doi.org/10.1021/JA952426X.

[42] K. Stokowa-Sołtys, A. Kasprowicz, J. Wrzesiński, J. Ciesiołka, N. Gaggelli, E. Gaggelli, G. Valensin, M. Jezowska-Bojczuk, Impact of $\mathrm{Cu} 2+$ ions on the structure of colistin and cell-free system nucleic acid degradation, J. Inorg. Biochem. 151 (2015) 67-74, https://doi.org/10.1016/j.jinorgbio.2015.05.011.

[43] S.W. Ho, D. Jung J.R. Calhoun, J.D. Lear, M. Okon, W.R.P. Scott, R.E.W. Hancock, S.K. Straus, Effect of divalent cations on the structure of the antibiotic daptomycin, Eur. Biophys. J. 37 (2008) 421-433, https://doi.org/10.1007/s00249-007-0227-2.

[44] V. Rangarajan, G. Dhanarajan, R. Sen, Improved performance of cross-flow ultrafiltration for the recovery and purification of $\mathrm{Ca} 2+$ conditioned lipopeptides in diafiltration mode of operation, J. Membr. Sci. 454 (2014) 436-443, https://doi. org/10.1016/j.memsci.2013.12.047.

[45] T. Sharma, N. Dohare, M. Kumari, UK. Singh, A.B. Khan, M.S. Borse, R. Patel, Comparative effect of cationic gemini surfactant and its monomeric counterpart on the conformational stability and activity of lysozyme, RSC Adv. 7 (2017)https://doi.org/10. 1039/c7ra00172j.

[46] D. Wu, G.Y. Xu, Y.H. Sun, H.X. Zhang, H.Z. Mao, Y.J. Feng, Interaction between proteins and cationic gemini surfactant, Biomacromolecules 8 (2007) 708-712, https://doi.org/10.1021/bm061033v.

[47] C. Duarte, EJ. Gudiña, C.F. Lima, LR Rodrigues, Effects of biosurfactants on the viability and proliferation of human breast cancer cells, AMB Express 4 (2014) 40, https://doi.org/10.1186/s13568-014-0040-0.

[48] L. Rodrigues, I.M. Banat, J. Teixeira, R. Oliveira, Biosurfactants: potential applications in medicine, J. Antimicrob. Chemother. 57 (2006) 609-618, https://doi.org/10.1093/ jac/dkl024.

[49] L.R. Rodrigues, Microbial surfactants: fundamentals and applicability in the formulation of nano-sized drug delivery vectors, J. Colloid Interface Sci. 449 (2015) 304-316, https://doi.org/10.1016/j.jcis.2015.01.022. 